\title{
CONTRIBUTION BETWEEN NEGLIGENT TORTFEASORS AND UNJUST ENRICHMENT: AN OUTLINE OF A SOLUTION TO THE "NO BENEFIT TO B" ISSUE
}

\author{
DAVID CHEIFETZ*
}

\begin{abstract}
Traditional understandings of contribution claims hold that a payment by one tortfeasor that benefits a second is a necessary element of a successful claim. However, circumstances may arise where that second tortfeasor gains immunity from liability after the common liability has already crystallized. These circumstances create an issue of "No Benefit to B." This article examines claims for contribution between tortfeasors where a "No Benefit to B" issue arises. It argues that, in such circumstances, an award for contribution is not always contrary to principle. The article also provides a judicial analysis that can be used to decide whether to allow a contribution claim to succeed in the context of the "No Benefit to B" issue.
\end{abstract}

\section{Table of Contents}

I. INTRODUCTION . . . . . . . . . . . . . . . . . . . . 879

II. The No Benefit to B IsSUE $\ldots \ldots \ldots \ldots \ldots \ldots \ldots . \ldots \ldots . \ldots \ldots . \ldots \ldots$

III. THE ANALYSIS $\ldots \ldots \ldots \ldots \ldots \ldots \ldots \ldots \ldots \ldots \ldots \ldots \ldots \ldots \ldots$

A. AN ENRICHMENT OF B . . . . . . . . . . . . . . . 886

B. A CORRESPONDING DEPRIVATION OF A THE ENRICHMENT IS AT A's EXPENSE $\ldots \ldots \ldots \ldots \ldots \ldots \ldots 88$

C. THE ABSENCE OF A JURISTIC REASON FOR THE ENRICHMENT THE ENRICHMENT IS UNJUST AND WHETHER THERE ARE ANy DefEnces Available to B . . . . . . . . . . . . . 891

IV. CONCLUSION ........................ 893

\section{INTRODUCTION}

Contribution is a label used to describe the remedy that $\mathrm{A}$ has against $\mathrm{B}$ to recover some portion of the money $\mathrm{A}$ paid to $\mathrm{C}$ that $\mathrm{C}$ could have recovered from either of $\mathrm{A}$ or $\mathrm{B}$, where A's payment to $C$ reduces the amount of B's liability to $\mathrm{C}$ by some portion of the amount of A's payment. ${ }^{1}$ The traditional justification for allowing $A$ to collect from $B$ is that A's payment benefits $\mathrm{B}$ to the extent that it reduces the amount of B's liability to $\mathrm{C}$. It is usually said that this benefit to $\mathrm{B}$ is a necessary element of a successful contribution claim. However, in some circumstances, an event occurs after the common liability of A and B to C came into

Currently studying at the Faculty of Law, St Hilda's College, Oxford. I thank Charles Mitchell and James Goudkamp for their recent comments on issues discussed in this article, and Lewis Klar, Vaughn Black, and Justice Russell Brown for their comments on these issues over the years. The usual disclaimer applies.

1 This article uses the basic contribution scenario: two tortfeasors, A and B, cause the same harm to an injured person, C. In this article, the contribution claimant is always A and the contribution defendant is always B. It is common, when discussing contribution between tortfeasors, to use D1 and D2, T1 and $\mathrm{T} 2$, or W1 and W2, with D, T, and W standing for defendant, tortfeasor, and wrongdoer, respectively, and $\mathrm{P}$ the injured person. I use "potentially liable" to indicate that B has not been sued by $\mathrm{C}$ but would, if sued, have been held liable in a correctly decided action. I use the generic A for the contribution claimant, $\mathrm{B}$ for the contribution defendant, and $\mathrm{C}$ for the injured person - the person to whom both $\mathrm{A}$ and $\mathrm{B}$ have a common obligation. I have done so rather than using some combination of $\mathrm{D}, \mathrm{T}, \mathrm{W}$, and $\mathrm{P}$, because I believe that the analysis is applicable, in principle, to contribution claims in all areas of joint obligation. 
existence which has the effect of providing $\mathrm{B}$, but not $\mathrm{A}$, with immunity to a claim by $\mathrm{C}$ in respect of the loss for which $\mathrm{A}$ and $\mathrm{B}$ once had the common liability. A pays $\mathrm{C}$ after that event occurs, at a time when $\mathrm{B}$ is no longer liable for any portion of the amount A pays to C. A then claims contribution from B. B's defence will be that the contribution claim must fail because of B's immunity to C's claim. B asserts that A's payment to C did not benefit $\mathrm{B}$ because $\mathrm{B}$ could not have been held liable for any portion of that amount, therefore $\mathrm{A}$ cannot establish a prerequisite for contribution. Will A's contribution claim succeed or fail?

In some circumstances, A's contribution claim will succeed notwithstanding B's immunity to $\mathrm{C}$ and notwithstanding that $\mathrm{A}$ 's payment to $\mathrm{C}$ seemingly does not benefit $\mathrm{B}$. Where there is no legislation that determines the result, the justification for allowing the contribution claim to succeed is said to be fairness as between A and B. It is said that there is something about the circumstances by which B acquired the immunity to C's claim that makes it unfair or unjust (the terms are used interchangeably and synonymously) as between A and B that B's immunity to C's claim deprive A of the right to contribution.

It is now accepted in Canadian and English case law and academic scholarship that the right to contribution between tortfeasors is a restitutionary remedy based on unjust enrichment, ${ }^{2}$ just as the contribution remedy is in other areas of obligations law. ${ }^{3}$ "[C]ontribution is concerned to effect restitution of an unjust enrichment." The traditional justification for this right of contribution is orthodox. Where $\mathrm{A}$ and $\mathrm{B}$ have a common liability to $\mathrm{C}$ in respect of C's loss, and A makes a payment to $\mathrm{C}$ that both reduces $\mathrm{B}$ 's liability to $\mathrm{C}$ and includes some portion of B's share of that common liability, justice and fairness require that $\mathrm{B}$ reimburse $\mathrm{A}$ for the amount paid to $\mathrm{C}$ that corresponds to $\mathrm{B}$ 's share of C's loss. ${ }^{5}$

More terminology: I use "gain" for "enrichment" and "loss" for "deprivation" when not quoting, when not using the phrase "unjust enrichment," and where the context does not require the formality of "enrichment" and "deprivation." "Liability" means that A, B, or both, have been held liable to C for C's loss by judgment or could have been held liable at some relevant time in the past. "Unjust Enrichment," when capitalized, refers to the area in the laws of obligation now given the label "Unjust Enrichment," to separate it from areas in the law of obligations labelled "Tort" or "Contract." When not capitalized, "unjust enrichment" refers to an aspect or consequence of the relationship between A and B upon which a restitutionary remedy - here contribution — is based, where the remedy is based on the principles of Unjust Enrichment or equivalent principles. The reason for the "Unjust Enrichment or equivalent principles" usage is explained in note 7. All references to the Supreme Court will be to the Supreme Court of Canada unless otherwise indicated.

3 It is now generally accepted in Canadian and English academic scholarship that there is a separate area of the law of obligations now given the label of "Unjust Enrichment": see Mitchell McInnes, The Canadian Law of Unjust Enrichment and Restitution (Markham: LexisNexis, 2014); Charles Mitchell, Paul Mitchell \& Stephen Watterson, eds, Goff \& Jones: The Law of Unjust Enrichment, 8th ed (London, UK: Sweet \& Maxwell, 2012). There is, however, at least in Canadian academic scholarship, a competing view that the area should be described as "Restitution," with "unjust enrichment" used to describe the basis of a remedy in Restitution: see Peter D Maddaugh \& John D McCamus, The Law of Restitution (Aurora, Ont: Canada Law Book, 2004); Lionel Smith, "The State of the Law of Unjust Enrichment in Common Law Canada" (2015) 57 Can Bus LJ 39.

$4 \quad$ Andrew Burrows, The Law of Restitution, 3rd ed (New York: Oxford University Press, 2011) at 459. See ibid at 455-59; Charles Mitchell, The Law of Contribution and Reimbursement (New York: Oxford University Press, 2003) at paras 1.01, 3.01-3.03 [Mitchell, Contribution]; Maddaugh \& McCamus, supra note 3 at 187; McInnes, supra note 3 at 160-61, 1213, 1221-22. 
This article examines claims for contribution between tortfeasors where the "No Benefit to B" (NBTB) issue exists. ${ }^{6}$ The issue is the apparent inconsistency with principle if contribution is allowed in an NBTB situation, assuming the result is not mandated by statute. The article argues that, under Unjust Enrichment principles, an award for contribution in the NBTB situation is not always contrary to principle. ${ }^{7}$ It contains the outline of an analysis which judges can use to decide whether to allow a contribution claim to succeed in the particular NBTB situation before the court. In practice, the common instance of this problem arises where $\mathrm{B}$ has acquired a limitation period defence to a claim by $\mathrm{C}$. A less common instance is where C settled with B for less than B's full share of C's loss and provided B a full release.

The common position asserted in the literature on contribution claims based on unjust enrichment, for those instances where B could never have been held liable to C, is that A's contribution claim must fail, absent a statutory provision requiring a different conclusion, because A's payment to $\mathrm{C}$ does not benefit $\mathrm{B}$ given $\mathrm{B}$ 's immunity to a claim by $\mathrm{C}^{8}{ }^{8} \mathrm{In}$ general, no distinction is made between instances where B's immunity from liability to $\mathrm{C}$ predates the event creating the common obligation or liability and instances where the immunity was acquired after the event. The NBTB issue is rarely discussed in the general literature except in brief reference to legislation governing contribution claims, where the legislation deals with some version of the NBTB issue. This legislation now exists. ${ }^{9}$

There is some consideration of the NBTB issue in texts focusing on contribution. However, there is rarely focused consideration as to whether the NBTB situation may be treated differently since B's immunity to a claim by $\mathrm{C}$ was acquired after the instantiation of the common liability; that is, after the instantiation of the common obligation or the occurrence of the tort. ${ }^{10}$ The statements of principle remain the same, regardless of the area

6 Unless otherwise indicated, the context is contribution between tortfeasors. I described it as an apparent or seeming problem in principle because it has long been considered a significant problem in claims for contribution between tortfeasors. Whether it ought to have been has a curious answer: see the text accompanying notes 10,15 , and 71 and the last two paragraphs of this article.

7 Taken literally, the current Canadian statement of the elements of a claim in Unjust Enrichment does not cover claims for contribution in either the ordinary or NBTB situation. B's gain and A's loss are not created by a payment by or on behalf of A to B. In the ordinary contribution situation A pays C. There is no sense in which that payment was made by mistake. In the NBTB situation, the event which creates B's gain, and ultimately A's loss should C claim from A, is C's decision to not sue B or C's decision to settle with B for less than B's share of C's loss. The issue of the proper classification of contribution is irrelevant to this article if contribution is governed by principles equivalent to those of Unjust Enrichment. The classification issue has not been answered in contribution literature. Mitchell, Contribution, supra note 5 does not attempt to provide an answer. Rather, Mitchell states at para 3.03 that the text "proceed[s] on the basis that claims for contribution ... should be classified as claims in unjust enrichment, regardless of whether they can also be classified as equitable claims, statutory claims, or claims at common law" because "[i]n principle ... there is no necessary opposition between the categories of 'equitable claim' and 'claim in unjust enrichment." I do not purport to suggest any solution to any of the outstanding issues in the meaning of the formal elements of the Canadian law of Unjust Enrichment, except to the extent that anything I write about Unjust Enrichment principles as they apply to contribution might imply an answer.

$8 \quad$ See e.g. Mitchell, Contribution, ibid at paras 3.14-3.17, 6.02-6.12, 12.01. The same position is taken in the limited discussions of contribution between tortfeasors in the texts on unjust enrichment and restitution: see e.g. McInnes, supra note 3 at 160-61; Maddaugh \& McCamus, supra note 3 at 187-88; Mitchell, Mitchell \& Watterson, supra note 3 at paras 19-01 to 19-05. The leading Canadian decision is Giffels Associates Ltd v Eastern Construction Co Ltd, [1978] 2 SCR 1346.

9 See note 14 , below.

10 See e.g. Mitchell, Contribution, supra note 5 at paras $12.01,12.31-12.33$. There is a somewhat more extensive discussion of the NBTB issue in David Cheifetz, Apportionment of Fault in Tort (Aurora, Ont: Canada Law Book, 1981) at 37-55, 151-53 (dealing with claims for contribution between tortfeasors under Canadian legislation). That discussion does not analyze the NBTB issue by reference to unjust 
of law: absent statute, A cannot obtain contribution from B where B is immune to C's claim because contribution requires that A's payment to $\mathrm{C}$ benefit $\mathrm{B}$ by discharging some portion of B's share of an existing common obligation or liability to $\mathrm{C} .{ }^{11}$

The NBTB problem does not, now, always have a clear statutory answer, even where the contribution right is a creation of statute. The problem did not have a clear answer in the original contribution statutes or related limitations of action legislation. ${ }^{12}$ Whether $\mathrm{B}$ has a defence to A's contribution claim before the limitation period for that claim has expired is not the same question as whether B has a defence to A's contribution claim because the limitation period for C's claim against B has expired. ${ }^{13}$ The NBTB problem now has an answer in some jurisdictions. The preferred modern answer, in statute and case law dealing with claims for contribution between tortfeasors, is the general rule that B's acquired immunity to the claim by $\mathrm{C}$ does not provide $\mathrm{B}$ a defence to A's contribution claim. ${ }^{14}$ If one takes a very expansive meaning of "modern" that proposition has also been true, at least in English law, in the area of contribution between co-debtors, co-sureties, and co-trustees, since the early $1890 \mathrm{~s}^{15}$ The justification provided in the case law and literature for allowing the contribution claim in the NBTB situation is fairness as between A and B: that as between $\mathrm{A}$ and $\mathrm{B}, \mathrm{B}$ will be unjustly enriched if $\mathrm{A}$ is denied contribution in respect of A's payment to $\mathrm{C}$ of B's share of C's loss. ${ }^{16}$

The basic premise upon which the proposed solution is based is this: under the principles of Unjust Enrichment or equivalent principles, it is the reason for B's acquired immunity to

enrichment principles, beyond asserting that the principles should be the same as those governing contribution between co-debtors (ibid at 41, 44-45). See notes 15, 71, and accompanying text, and the penultimate paragraph to this article, for the law governing the NBTB situation in claims for contribution between co-debtors.

11 See e.g. Mitchell, Contribution, supra note 5 at paras 6.02, 6.05-6.12, 12.01, 12.31-12.33. Cf note 15 and associated text (dealing with a historically different rule for contribution between co-debtors).

See e.g. in Canada, the legislation in Waterloo Region District School Board $v$ CRD Construction Ltd, 2010 ONCA 838, 103 OR (3d) 81; Strata Plan LMS 1751 v Fairchild Projects No 12 Ltd; Strata Plan LMS 1751 v Scott Management Ltd, 2010 BCCA 192, 318 DLR (4th) 567, leave to appeal to SCC refused, 33740 (25 November 2010) [Strata]; Sealed Air (Canada) Co/Cie v Scott Management Ltd, 2010 CanLII 69205 (SCC); MacKenzie v Vance (1977), 19 NSR (2d) 381 (CA) [MacKenzie]; Sun Life Assurance Co of Canada v 671095 Alberta Ltd, 2011 ABCA 234, 341 DLR (4th) 30 [Sun Life].

13 These questions are sometimes still conflated. They should not be.

14 See e.g. the United Kingdom's Civil Liability (Contribution) Act 1978 (UK), c 47, s 1(3): “A person shall be liable to make contribution ... notwithstanding that he has ceased to be liable in respect of the damage in question since the time when the damage occurred, unless he ceased to be liable by virtue of the expiry of a period of limitation or prescription which extinguished the right on which the claim against him in respect of the damage was based." The Alberta Limitations Act, RSA 2000, c L-12, s 3(1.2) [Limitations Act AB] provides: "For greater certainty, no claim for contribution against a defendant in respect of damage referred to in section 3(1)(c) of the Tort-feasors Act is barred by the expiry of a limitation period within which the person who suffered that damage could seek a remedial order."

15 See Glanville L Williams, Joint Obligations (London, UK: Butterworth, 1949) at 165-66, 169, n 1. Williams wrote at 165-66: "The right of contribution ...does not depend on a present common obligation between the debtor who pays the debt and the debtor against whom ... contribution is sought. It is enough that the joint or joint and several obligation existed at some period in the past." The proposition is repeated ibid at 169. The cases cited are English decisions from the 1890s. Williams set out the same position on claims for contribution between tortfeasors in Glanville Williams, Joint Torts and Contributory Negligence: A Study of Concurrent Fault in Great Britain, Ireland and the CommonLaw Dominions (London, UK: Stevens \& Sons, 1951) at 97-98, 132. He stated that "the problem should be resolved on the analogy of the settled rule in contract and trusts" (ibid at 132). See e.g. supra note 12 and the law reform reports cited in note 27 , below. 
C which governs, not the mere fact of B's immunity. ${ }^{17}$ The mere fact of that immunity does not provide $\mathrm{B}$ a defence. This premise produces the solution to the NBTB problem outlined in the next paragraph. I emphasize, here, that this premise is bedrock. If it is not accepted, then the analysis fails. There is no principled basis, internal to unjust enrichment principles or unique to contribution principles, to reject the premise. If it is to be rejected, the basis for the rejection is normative; that is, social policy reasons extrinsic to law.

For the purposes of a contribution claim by A against B:

(1) A's loss and B's gain need not be linked together, initially, by some positive act performed by A, for example, payment by A to $\mathrm{C}$. The loss and gain, upon which A's contribution claim is based, may also be linked by an act or omission by $\mathrm{C}$, for example, failure by $\mathrm{C}$ to sue $\mathrm{B}$ within a relevant limitation period or settlement by C with B for less than B's share of C's loss.

(2) A's loss for the purpose of contribution, which instantiates when A makes the payment to $C$ upon which A's claim for contribution against $B$ is based, need not have chronologically preceded B's gain before it can be said that A's loss and B's gain are relevantly linked together.

(3) The normative considerations that inform the second and third elements of a cause of action in Unjust Enrichment, or a cause of action governed by equivalent principles, do not entail the conclusion that the mere fact that $\mathrm{B}$ has ceased to be liable to $\mathrm{C}$ is a sufficient defence to A's contribution claim. What matters is the reason for B's immunity to $\mathrm{C}$.

(4) If these propositions are accepted, then it follows that a claim in or based on unjust enrichment may lie against $\mathrm{B}$ for contribution even if $\mathrm{B}$ has ceased to be liable to $\mathrm{C}$ at the time when A pays $\mathrm{C} .{ }^{18}$

The propositions at (1) and (2) in this solution satisfy the factual components of the first and second elements of the test for a claim in Unjust Enrichment. The social policy considerations implicit in the second element and explicit in the third element of the test are covered in the proposition at (3). Together, propositions at (1), (2), and (3) form the framework for the analysis which will provide the answer, in principle, to the NBTB problem, assuming the answer for the particular case is not provided by statute.

This article asserts that the question in the NBTB situation is whether to allow or deny the contribution claim on the basis of the reason for B's immunity to a claim by $\mathrm{C}$. The analysis outlined in this article permits either a "yes" or "no" answer, depending on the facts of the particular case while being agnostic as to which answer is the correct answer. For Canadian law, it is the answer to the question: "Is there an absence of juristic reason for B's

17 An analysis based on this premise does not entail a distinction between situations where: (1) B could never have been held liable to C; and (2) B has acquired that immunity. This article deals only with the latter situation.

18 The core of the summary as contained in propositions (1), (2), and (4) was provided to me by Charles Mitchell in an email dated 8 November 2015. I am extremely grateful. I slightly paraphrased that version for this article and inserted the proposition at (3). 
enrichment?" where the mere fact of B's immunity to C does not require the court to find that the immunity is a sufficient reason for B's gain. Everything else in this article is detail. ${ }^{19}$

\section{The No Benefit To B ISSUE}

The common example in practice is where the limitation period governing C's claim against $\mathrm{B}$ expired before the earlier of the time when A paid $\mathrm{C}$ or $\mathrm{A}$ could have commenced a contribution claim against $\mathrm{B}$. The apparent result of B's immunity to a claim by $\mathrm{C}$ is that $\mathrm{B}$ seems to derive no benefit from the fact of A's payment to $\mathrm{C}$, because that payment does not discharge or reduce an existing or potential liability that $\mathrm{B}$ has to $\mathrm{C}$. $\mathrm{B}$ asserts that immunity to $\mathrm{C}$ necessarily provides $\mathrm{B}$ a complete defence to A's contribution claim, absent legislation that provides otherwise. ${ }^{20}$

I wrote "seems to derive no benefit" because, in some situations, B's immunity to C's claim formally relates only to C's remedy. It does not extinguish C's right. The immunity is procedural not substantive. In those situations, it is possible that some conduct on the part of $\mathrm{B}$ could preclude $\mathrm{B}$ from relying on that immunity in the event that $\mathrm{C}$ chooses to sue $\mathrm{B}$. The situation where B's immunity to a claim by $C$ is based on the expiration of the limitation period applicable to C's claim against B is usually one example of procedural immunity. However, there are statutes that provide that the expiration of the limitation period extinguishes the right, not just the remedy. ${ }^{21}$ I ignore the distinction between the two types of limitation period defence in the balance of this article, as it does not create, in principle an issue which requires separate consideration. ${ }^{22}$

The NBTB problem is contentious. It has been mentioned in scholarship since at least the mid-1930s and explicitly considered in that scholarship since at least $1940 .^{23}$ The solution requires balancing the "competing social values" involved in the recognition of A's, B's, and C's rights as against one another where: (1) if A loses the contribution right it is as a result of conduct by $\mathrm{C}$ in relation to $\mathrm{C}$ 's claim against $\mathrm{B}$; and (2) a social policy decision has already been made that, in principle, $C$ 's rights against $A$ will not be impaired merely because of C's decision to not collect B's share of C's loss from B. ${ }^{24}$ It has been described as a "difficult question [for which] powerful arguments can be made on both sides of this

The analysis applies equally well to ordinary contribution situations where B asserts some reason why A's contribution claim should not be permitted even though, prima facie, A has satisfied all of the formal requirements. One situation could be any version of a "change of position" defence.

$20 \quad$ See supra note 12.

$21 \quad$ See e.g. Real Property Limitations Act, RSO 1990, c L.15 ("[a]t the determination of the period limited by this Act to any person for making an entry or distress or bringing any action, the right and title of such person to the land or rent, for the recovery whereof such entry, distress or action, respectively, might have been made or brought within such period, is extinguished," s 15); Limitation Act 1980 (UK), c 58: ("at the expiration of the period prescribed by this Act for any person to bring an action to recover land (including a redemption action) the title of that person to the land shall be extinguished," s 17). Probable examples are provisions in legislation which provide an "ultimate" limitation period, see e.g. Limitations Act AB, supra note 14, s 3; Limitations Act, 2002, SO 2002, c 24, Schedule B, s 15 [Limitations Act ON].

22 The effect of the expiration might be a factor relevant to the ultimate decision whether or not to allow the contribution claim. If so, this an example of the premise that what is relevant is the explanation for the immunity, not the mere fact of the immunity.

23 See Arthur Larson, "A Problem in Contribution: The Tortfeasor with an Individual Defense Against the Injured Party" [1940] 4 Wis L Rev 467 at 480-83.

24 McInnes, supra note 3 at $1216-17$. 
issue, and no result may be completely satisfactory." 25 Nonetheless, there is no valid reason why C "simply by selecting one source of relief over others, should have the power to determine the ultimate allocation of burdens between the obligated parties." 26

The unanimous (to my knowledge) recommendations of law reform commissions are that B's limitation period based immunity to C's claim should not, of itself, defeat A's contribution claim against B. ${ }^{27}$ "It cannot be thought fair that the success of D1's claim for contribution against D2 will depend on whether P did or did not attempt to take action against D2." ${ }^{28}$ Using the same justification, the predominant, modern, case law conclusion, absent the conclusion that the governing statute mandates otherwise, is that C's limitation period based immunity to B's claim does not provide B with a defence to A's contribution claim. $^{29}$

The modern, statutory, solution is an attempt to balance the rights of A and B through the limitation period assigned to A's contribution claim against B, regardless of whether there is legislation dealing specifically with the effect or non-effect of B's limitation period defence to a claim by $\mathrm{C}$. Under traditional limitations of action legislation, the contribution limitation period did not start to run until A settled with $\mathrm{C}$ or was held liable to $\mathrm{C}$. Under some of the new forms of limitations legislation, the contribution claim limitation period starts to run on the day that $\mathrm{A}$ is served with the documents that instituted C's action against A. ${ }^{30}$

The position taken in the leading modern treatises on contribution is that, in principle, because contribution claims are claims in unjust enrichment, B's limitation period-based immunity to C's claim should provide B a defence to A's contribution claim because B will not be enriched by A's payment. ${ }^{31}$ Academic scholarship and case law have not, to date,

Ontario Law Reform Commission, Report on Contribution among Wrongdoers and Contributory Negligence (Toronto: Ministry of the Attorney General, 1988) at 157, and generally at 141-60 [OLRC Report].

26 McInnes, supra note 3 at 1217; see also OLRC Report, ibid. The point has also been made explicitly in numerous law reform commission reports, not just those listed in note 27 , below.

27 See e.g. Manitoba Law Reform Commission, Contributory Fault: The Tortfeasors and Contributory Negligence Act (Winnipeg: Manitoba Law Reform Commission, 2013) [MLRC Report]; New South Wales Law Reform Commission, Contribution between Persons Liable for the Same Damage, Report 89 (Sydney: New South Wales Law Reform Commission, 1999) [NSWLRC Report]; OLRC Report, ibid; United Kingdom Law Commission, Law of Contract Report on Contribution (London: Her Majesty's Stationery Office, 1977) [EWLC Report]. There have been others. Some are mentioned in the MLRC Report, ibid.

28 NSWLRC Report, ibid at 86.

29 In Canada, all the cases involve a statutory right of contribution: see e.g. Strata, supra note 12 at para 57 (contribution allowed); MacKenzie, supra note 12 at 390 (contribution allowed). Contra Canada Deposit Insurance Corp v Prisco, 1998 ABQB 163, 221 AR 44; Sun Life, supra note 12 at paras 27-38 (claim denied on the basis of C's contractual immunity to B). The Canadian case law is reviewed in the MLRC Report, supra note 27 at 69-74; OLRC Report, supra note 25 at 141-60. The "fairness as between A and B" justification is the usual basis for permitting contribution in the NBTB situation in those states of the United States where the claim is allowed: see Andrew Kull, "The Source of Liability in Indemnity and Contribution" (2003) 36:2 Loy LA L Rev 927.

30 See e.g. Limitations Act AB, supra note 14, s 3(1.1); Limitations Act ON, supra note 21, s 18.

31 See Mitchell, Contribution, supra note 5 at para 6.05. I have asserted the opposite conclusion based on Unjust Enrichment principles where B's defence to C's claim is procedural only - a defence to the remedy not the right — as in the case of most limitation period defences: David Cheifetz, "Silk Purses and Silver Linings: Waterloo Region District School Board v. CRD Engineering Ltd." (2011) 38:3/4 Adv Q 371 at 386-408. Whether the "you can't do indirectly what you can't do directly: make B pay B's share of C's loss" explanation in Sun Life, supra note 12, is an adequate explanation is open for debate. I see it as merely a conclusion, not an explanation for the conclusion. 
provided an adequate, principled, explanation for the position that A's contribution claim should not be defeated merely because B has a limitation period defence to C's claim, assuming statute does not dictate the result. The position that it is unfair as between $\mathrm{A}$ and $\mathrm{B}$ that C's actions dictate the result is justification for that conclusion. Fairness is a sufficient explanation only if the jurisprudential basis of the contribution claim dictates that fairness as between $\mathrm{A}$ and $\mathrm{B}$ is a sufficient answer. ${ }^{32}$

The solution outlined in this article for the NBTB problem is provided by an analysis which is premised on the assumption that the principles of Unjust Enrichment or equivalent principles apply to a claim for contribution between negligent tortfeasors, ${ }^{33}$ as these requirements are currently defined in Canadian law. ${ }^{34}$

\section{The Analysis}

The question as to whether to allow or not allow contribution in NBTB situations is analyzed within the frameworks established by the three-part Canadian law analysis of the elements of a cause of action based on unjust enrichment and the three- or four-part English law analysis. In Canadian law, the elements of a cause of action in unjust enrichment are: (1) an enrichment of B; (2) a corresponding deprivation of A; and (3) the absence of a juristic reason for the enrichment. ${ }^{35}$ In English law, the elements of a claim in unjust enrichment are: (1) an enrichment of B; (2) the enrichment is at A's expense; (3) the enrichment is unjust; and (4) whether any defences are available to B. ${ }^{36}$

\section{A. An EnRichment Of B}

In principle, there are no valid reasons for a position that, in the NBTB situation, B's gain as a result of C's conduct is not capable of satisfying the first element.

In joint, or joint and several, liability regimes, $\mathrm{B}$ is financially better off than $\mathrm{B}$ would be if $\mathrm{C}$ sought to recover from $\mathrm{B}$ alone. $\mathrm{B}$ is still better off even if $\mathrm{A}$ is ultimately able to recover

32 It might well be if contribution claims, generally, or just contribution claims as between tortfeasors, are governed entirely by historical principles of equity and the common law and not by the principles of Unjust Enrichment or equivalent principles. Some authors describe contribution that way: see e.g. Maddaugh \& McCamus, supra note 3 at 187-200. Equitable principles (and common law principles said to be the same) are the reason why B's acquired limitation period defence to a claim by $\mathrm{C}$ does not provide $\mathrm{B}$ a defence if $\mathrm{A}$ and $\mathrm{B}$ are co-debtors. As between co-debtors, the right of contribution does not depend on the existence of a "present common obligation" between A and B. It is sufficient that the common obligation once existed: see supra note 15 and the penultimate paragraph of this article, below. In principle, it seems the analysis is applicable to intentional tortfeasors as well. I do not go beyond that general statement.

34 As the focus of this article is Canadian law, cases cited for the principles of Unjust Enrichment are decisions of the Supreme Court of Canada with one reference to a recent decision of the Supreme Court of the United Kingdom. In principle, the analysis should apply to English law too. As is shown in this article, the steps in the analysis, in at least one situation, better fit the labels used in English law for the formal elements of a claim in Unjust Enrichment.

35 See e.g. Kerr v Baranow, 2011 SCC 10, [2011] 1 SCR 269 at paras 31-41 [Kerr]; Garland $v$ Consumers' Gas Co, 2004 SCC 25, [2004] 1 SCR 629 [Garland] ("[t]he cause of action has three elements: (1) an enrichment of the defendant; (2) a corresponding deprivation of the plaintiff; and (3) an absence of juristic reason for the enrichment" at para 30$)$.

36 See Menelaou v Bank of Cyprus UK Ltd, [2015] UKSC 66, [2016] AC 176 at para 18 [Bank of Cyprus] for a statement of the English law. I thank Charles Mitchell for alerting me to this decision. 
contribution from B. Contribution liability is several. ${ }^{37}$ The most $\mathrm{A}$ will be able to recover is the amount A paid to C in excess of A's share of C's loss, up to the limit of B's share. ${ }^{38}$ At the first stage of the unjust enrichment analysis, the only question is whether $\mathrm{B}$ has been enriched. B has been.

In the ordinary contribution situation, where $\mathrm{B}$ does not have any immunity to a claim by $\mathrm{C}$ for loss resulting from harm caused by both $\mathrm{A}$ and $\mathrm{B}, \mathrm{B}$ is enriched when A pays any portion of the commonly caused loss. $\mathrm{B}$ is enriched because A's payment also reduces the maximum limit of B's potential liability to $\mathrm{C}$ by at least the amount of the payment. $\mathrm{B}$ benefits contemporaneously from the fact of A's payment to C. ${ }^{39}$ In the NBTB situation, this contemporaneous gain as a result of the payment by $\mathrm{A}$ to $\mathrm{C}$ does not exist. Where $\mathrm{B}$ has become immune to liability to $\mathrm{C}$, A's payment to $\mathrm{C}$ does not, seemingly, discharge any existing liability that $\mathrm{B}$ has to $\mathrm{C}^{40}$

In Canadian law, the "has B been enriched" question is to be answered using a "straightforward economic approach." 41 The difference between B's gain in the standard contribution situation and the NBTB situation is that B's gain is the result of the conduct of $\mathrm{C}$ not A. This difference is not relevant in a "straightforward economic approach." The significance, if any, of that distinction is a matter for analysis in the context of the second or third elements of the test for an unjust enrichment. Accordingly, the first element of the test for an unjust enrichment should not pose a problem in the NBTB contribution situation. ${ }^{42}$ There is an incontrovertible benefit to B where A pays $\mathrm{C}$ at least some portion of B's share of C's loss. B's gain is “demonstrably apparent and not subject to debate and conjecture." 43 It is tangible. It is a negative benefit because B is spared the expense of paying at least A's share and, if A does not have a contribution right, B's own share. ${ }^{44}$ B's benefit can be restored to $\mathrm{A}$ in money. ${ }^{45}$

B will never be liable to A for more than B's share of C's loss. In the event that A pays C some portion of B's share and B is held liable to pay A some amount, B is no worse off than B would have been if C had collected only B's share from B.

38 This is significant where there are three or more tortfeasors. A cannot recover any portion of the shares of the other tortfeasors from B, absent vicarious liability or some other basis of recovery other than contribution.

39 A's right to contribution does not arise until A pays more than A's share. That, however, is irrelevant to the question of whether B benefits from A's payment.

40 At most, it discharges a potential liability that will instantiate if something occurs that precludes B from relying on the basis of B's immunity to C.

41 See Kerr, supra note 35 at para 37; Garland, supra note 35 at para 31; Pacific National Investments Ltd $v$ Victoria (City), 2004 SCC 75, [2004] 3 SCR 575 at para 15.

42 As stated, this article proceeds on the assumption that Unjust Enrichment principles govern claims for contribution between tortfeasors including the NBTB situation. One could argue that the NBTB situation does not fit the current statements of the conditions for satisfying at least the first two elements of a claim based in Unjust Enrichment. In Kerr, supra note 35 at para 38, the Supreme Court wrote that "[f]or the first requirement - enrichment - the plaintiff must show that he or she gave something to the defendant which the defendant received and retained." In the NBTB situation, it is C's act and not A's act that creates B's actual gain. C is in no sense a proxy for A. It may be, however, that that requirement will be relaxed or modified as appropriate to deal with different types of unjust enrichment situation: see Pro-Sys Consultants Ltd v Microsoft Corporation, 2013 SCC 57, [2013] 3 SCR 477 at paras 86-87 [Pro-Sys]; Sun-Rype Products Ltd v Archer Daniels Midland Company, 2013 SCC 58, [2013] 3 SCR 545 at paras 36-37 [Sun-Rype]; Smith, supra note 3. See also, Kerr, ibid at paras 71-73, where Justice Cromwell notes the need for "remedial flexibility."

$43 \quad$ Peel (Regional Municipality) v Canada; Peel (Regional Municipality) v Ontario, [1992] 3 SCR 762 at 795.

$44 \quad$ See Kerr, supra note 35 at para 38; Garland, supra note 35 at paras 31, 37. Kerr, ibid. 
In addition, as mentioned, B has an immediate gain in some situations, even in the NBTB situation: in those cases where B's limitation period-based immunity is procedural, not substantive. In these cases, A's payment to $\mathrm{C}$ reduces the extent to which $\mathrm{B}$ could be liable to $\mathrm{C}$ in the event that if something occurs which prevents $\mathrm{B}$ from relying on that defence against $\mathrm{C}$. This may be a potential gain; nonetheless, it is a gain.

\section{B. A CORRESPONDING DEPRIVATION OF A - THE ENRICHMENT Is AT A's EXPENSE}

This element requires an examination of the causal connection that must exist between B's gain and A's loss.

In order "[f]or the unjust enrichment principle to apply ... some connection must be shown between the ... [enrichment] and corresponding deprivation." ${ }^{46}$ The enrichment and deprivation are "the same thing from different perspectives" $"$ and are "two sides of the same coin. ${ }^{" 48}$ The meaning of the Canadian statement of the test for the second element - whether there is corresponding deprivation of $\mathrm{A}$ - is not self-evident if it requires anything more than a causal connection. The jurisprudence is unsettled. ${ }^{49}$ There are two aspects of this element: the first being whether A's loss is a loss to which unjust enrichment principles apply and the second whether unjust enrichment principles extend to claims which are for more than just A's loss, such as disgorgement of B's gain in excess of A's actual loss. ${ }^{50}$ The first aspect is considered in this article. The second is not. It is not relevant because, in the contribution context, A's claim is only for the amount of A's payment to $\mathrm{C}$ that corresponds to B's share of C's loss.

There is necessarily some type of factual connection between B's gain and A's loss in the NBTB situation. C's conduct created B's gain. C's conduct created the potential for A's loss. B's gain is a necessary condition of A's loss because C can recover twice. For contribution purposes, A's actual loss manifests when C requires A to pay some portion of B's share of the loss caused by both A and B; that is, more than A's share and A pays that amount. The question is whether those facts amount to a causal connection between B's gain and A's loss sufficient to satisfy the "corresponding deprivation" requirement.

In principle, the connection between B's gain and A's loss, in the NBTB situation, is sufficient for the second element of the test for a claim based in Unjust Enrichment or on equivalent principles. It is necessarily sufficient to satisfy the factual aspect of the "corresponding deprivation" requirement. That ought to be enough. I see no principled reason for a conclusion that, as a matter of law, there are some other factors that must be

Professional Institute of the Public Service of Canada v. Canada (Attorney General), 2012 SCC 71, [2012] 3 SCR 660 at para 151.

$48 \quad$ Peter v Beblow, [1993] 1 SCR 980 at 1012.

49 See Smith, supra note 3; McInnes, supra note 3, ch 3. For present purposes, the questions seem to be shrouded in uncertainty over how "direct" the connection between the loss and gain must be. See notes $51-54$ and associated text, below.

50 McInnes, ibid ("the Canadian formulation of the second element of the common law concept of unjust enrichment serves two important functions: standing to sue and quantification of restitution" at 143 [emphasis in original]). 
satisfied, whatever these might be, which the causal connection between B's gain and A's loss is not capable of satisfying in the NBTB situation.

If there is a legal issue as to whether the causal connection between A's loss and B's gain in the NBTB situation is capable, in law, of satisfying the "corresponding deprivation" condition, it is because the connection seems to be "indirect" rather than "direct." 51 In this sense, "direct" describes the causal connection that exists in the ordinary contribution claim where it is the fact of A's payment to C, while B is still potentially liable to $C$, that creates A's loss and B's gain for the purposes of the contribution claim. In the ordinary contribution situation, A creates B's gain when A pays any portion of C's loss. A creates the portion of B's gain to which contribution applies when A pays C more than A's share of C's loss. A's payment to C, of some portion of B's share of C's loss, while B is still exposed to being held liable to pay $\mathrm{C}$ that amount, contemporaneously enriches B. B's liability to $\mathrm{C}$ has been reduced by a payment that the law deems to have been made on behalf of $\mathrm{B}$ for contribution purposes, because A has paid some portion of B's share of C's loss. If this is what "direct" means, then the causal connection between A's loss and B's gain in the NBTB situation is different and may be something other than "direct" for the purposes of unjust enrichment principles.

In the NBTB situation, C creates, or is responsible for, B's gain by choosing to not sue, or otherwise collect from, B. That creates the potential for A's loss which instantiates when $\mathrm{C}$ then collects from $\mathrm{A}$. Assuming A still has the contribution right, A satisfies the conditions for the exercise of that right when A pays C some portion of B's share of C's loss. The notionally contemporaneous relation between B's gain and A's loss which exists in the ordinary contribution situation does not exist in the NBTB situation. In the latter, B's gain is contemporaneous with only A's potential loss. It precedes both A's actual loss which instantiates when A pays $\mathrm{C}$ and the portion of that loss which instantiates when A pays any portion of B's share to C. Even if this could be a relevant difference - I assert it is not which once might have made a difference under the "direct connection" requirement that difference no longer matters. ${ }^{52}$ It appears that there is no longer a "directness" requirement in the second element even if there once was. ${ }^{53}$ In addition, it has been suggested that there could never have been such a requirement for contribution claims where, by definition, the

51 I have chosen to discuss this issue notwithstanding that the premise of this article is that the facts of contribution claims between tortfeasors, generally, and in NBTB situations fit within the stated elements of the Canadian version of the test for a cause of action in Unjust Enrichment. One reason is to show one of the difficulties I had in "shoehorning" contribution formally into Unjust Enrichment.

52 This is apart from the fact that this article proceeds on the assumption that this could not be a relevant difference.

See Pro-Sys, supra note 42 at paras 86-87; Sun-Rype, supra note 42 at paras 36-37; Smith, supra note 3 at 12 . The Supreme Court stated in Pro-Sys, that it is no longer "plain and obvious that a claim in Unjust Enrichment will be made out only where the relationship between the plaintiff and the defendant is direct" (ibid at para 87). This was later affirmed in Sun-Rype. The fact that, in Pro-Sys, the issue arose at the "juristic reason" stage is not relevant to the point under discussion, as the argument amounted to an attack on the sufficiency of the factual connection between the gain and the loss. In Bank of Cyprus, supra note 36, the Supreme Court of the United Kingdom dispensed with any requirement that the payment (transfer of wealth) flow directly from the person suffering the loss to the person receiving the benefit. 
relation between B's gain and A's loss is “indirect," since B's gain never results from a payment by $\mathrm{A}$ to $\mathrm{B}^{54}$

The answer to whether there is a sufficient casual connection, in the NBTB situation, is necessarily, undeniably, "yes" if the test for the adequacy of the causal connection is stated in the English law form: was B's gain acquired "at the expense of A." 55 The English form makes it clear that the courts are not inquiring into how A's loss occurred, or who caused A's loss, except to the extent that those issues are relevant to the question of whether B's gain was at A's expense. The current explanation of the meaning of "at the expense of" A in English law is found in Bank of Cyprus: "[w]hether a particular enrichment is at the expense of the claimant depends on the facts of the case. The question in each case is whether there is a sufficient causal connection, in the sense of a sufficient nexus or link, between the loss to $[\mathrm{A}]$ and the benefit received by $[\mathrm{B}] .{ }^{, 56}$

In the NBTB situation, there is no principled basis for asserting that B's gain is not at A's expense. In the contribution situation, where by definition the facts involve at least three persons, A, B, and C, the connection between A and B is always indirect because A never pays B. Some payment (or lack of payment) to C creates B's gain and A's loss, or potential for loss. What is relevant about the connection between the event that creates B's gain and A's loss is whether the event discharges, or could have discharged, some portion of a common liability that A and B owe or once could have owed to C. It is not the existence of some aspect of the connection between the gain and the loss that somehow does or does not qualify as "direct."

There is, in principle, nothing intrinsic to the right of contribution, separate from its status as a remedy in unjust enrichment, that necessitates a condition of the right to contribution be that the instantiation of the gain and loss be contemporaneous or that the loss at least notionally precede the gain. There is now very recent, explicit, judicial authority for the proposition that, in a claim in unjust enrichment, the gain may predate the loss: Bank of Cyprus. $^{57}$

This is the conclusion to be drawn from McInnes, supra note 3 at 143-44 [emphasis in original]: Proof of a corresponding deprivation or expense provides standing to sue. Accepting that the defendant has no right to retain a benefit obtained without juristic reason, a question remains as to why the plaintiff — as opposed to some other party — is the proper object of the remedial response. It is the nexus between the parties that provides the answer. The fact that the benefit received by the defendant was subtracted from the plaintiff explains why the former is ... liable to the latter.

The word omitted at the elision is "strictly." The implications of that concept are not relevant to the issues discussed in this article. It is also the conclusion to be drawn from ibid at 1222 (at the text associated with the heading "Claimant and Defendant"); at 1224-25 (under the heading "Discharge of a Debt" and the subheading "No Debt to Discharge"); and, specifically in relation to contribution claims, at 1239-40 (under the headings "Common Liability" and "Corresponding Deprivation"). It is true that at 1239 , McInnes wrote that for unjust enrichment purposes " $\mathrm{t}]$ he only thing that matters is that the claimant has discharged a debt and thereby saved the defendant a necessary expense." However, that proposition should not be taken literally and out of context. McInnes was not discussing contribution in the NBTB situation. The quoted statement refers to the argument, sometimes made in respect of contribution claims, that A's and B's obligations to C must arise from the same legal source (e.g. that both lie in contract or in tort).

$55 \quad$ Bank of Cyprus, supra note 36 at para 27; Mitchell, Contribution, supra note 5 at para 3.18.

Bank of Cyprus, ibid.

Ibid at para 34 (the benefit occurred about one month before the loss occurred). 
In any event, the statements by the Supreme Court about the loosening of the "direct" connection requirement ${ }^{58}$ and that the inquiry into the existence of both the "enrichment" and "corresponding deprivation" elements ${ }^{59}$ is a "straightforward economic approach" ${ }^{\circ 0}$ with "moral and policy arguments" left for the "absence of juristic reason stage" preclude any inquiry, at the "corresponding deprivation stage," into the question of whether the factual causal connection between the enrichment and the loss is a sufficient legal causal connection. It is enough that it is a causal connection.

If the causal connection between B's gain and A's loss is enough, as a matter of law, to satisfy the requirements of the "corresponding deprivation" condition, then the analysis proceeds to the third element: the juristic reasons stage. The "corresponding deprivation" inquiry is finished. However, if it is not, then in a particular case the court will have to decide if the causal connection is sufficient as a matter of law, based on whatever considerations the applicable jurisprudence mandates as relevant. That decision will include social policy considerations; that is, factors extrinsic to the connection between the parties to the action but relevant to unjust enrichment and contribution law as a whole. In theory and practice, it seems sensible to consider this issue at the juristic reasons stage, while bearing in mind that it amounts to a form of preliminary question. ${ }^{62}$

\section{The AbSence of A JuRistic Reason for the ENRICHMENT - THE ENRICHMENT IS UNJUST AND Whether There Are Any Defences Available to B}

In Kerr, the Supreme Court wrote: "The Court has taken a straightforward economic approach to the first two elements - enrichment and corresponding deprivation. Accordingly, other considerations, such as moral and policy questions, are appropriately dealt with at the juristic reason stage of the analysis." ${ }^{\prime 63}$ The analysis in this article, because it weaves in considerations unique to the contribution question, implies that there are normative questions, at least in relation to the "corresponding deprivation" element, that are better handled at this stage than the "corresponding deprivation" stage.

To assert that the gain occurred without juristic reason is to assert "that there is no reason in law or justice for [B's] retention of the benefit conferred [on B], making its retention 'unjust' in the circumstances of the case." ${ }^{\text {" }}$ What constitutes "absence of juristic reason" is beyond the scope of this article. What constitutes "absence of juristic reason" is relevant only in the sense that those conditions will be employed by this analysis.

Pro-Sys, supra note 42 at paras 86-87; Sun Rype, supra note 42 at paras 36-37.

Pro-Sys, ibid.

Kerr, supra note 35 at para 37; Garland, supra note 35 at para 31.

Kerr, ibid; Garland, ibid.

Given the structure of the proposed analysis, my intuition is that it does not matter where the social policy decisions are made so long as the court makes it clear at which level the decision is made.

Kerr, supra note 35 at para 37. See also paras 40-45 for the current outline of the Canadian "absence of juristic reason" jurisprudence.

Kerr, ibid at para 40. The complete quotation is: "To put it simply, this means that there is no reason in law or justice for the defendant's retention of the benefit conferred by the plaintiff, making its retention 'unjust' in the circumstances of the case." For reasons discussed, this quotation should not be understood to restrict unjust enrichment to situations where A actually conferred the benefit on B. 
There is no analogy, at this stage, between the ordinary contribution situation and the NBTB situation. The question, here, is whether there is something about the NBTB situation, other than the mere the fact of C's immunity to B, alone, that requires the conclusion that the fact of that immunity provides $\mathrm{B}$ a defence to the contribution claim. This article asserts that if there is something, that factor has to be something about the explanation for B's immunity to $\mathrm{C}$, not the mere fact of B's immunity.

At the juristic reason stage, the premise that it is the explanation for the immunity, not the mere fact of the immunity, that matters to the question of whether to allow A's contribution claim in the NBTB situation keeps the analysis subservient to and consistent with the structure and content of the elements of a cause of action in Unjust Enrichment.

If one accepts that the analysis proposed in this article allows one to reach the third unjust enrichment element, then the mere fact of B's immunity to C cannot be a defence to A's contribution claim in every case. If that were so, there could not have been a corresponding loss. Similarly, the mere fact that, in a joint, or joint and several, liability regime, $\mathrm{C}$ is not required to sue or attempt to recover from B; C's attempt to recover all of C's loss for $\mathrm{A}$ is lawful; and C's enrichment, A's potential loss, A's actual loss and C's immunity to B, are all consequences of lawful conduct; cannot provide B a defence to A's contribution claim in every case.

If the mere fact of C's immunity to a claim by B is not a valid juristic reason for the enrichment, is there something else that could be? In the ordinary NBTB situation where the source of B's immunity to a claim by $\mathrm{C}$ is the expiration of the limitation period governing a claim by $\mathrm{C}$ against $\mathrm{B}$ in respect of the harm caused by both $\mathrm{A}$ and $\mathrm{B}$, there is nothing about A's conduct that played any part, let alone any relevant part, in B's acquisition of the immunity. If it is not one of the ordinary defences to a claim in unjust enrichment such as change of position or the contribution equivalent - laches - then it would have to be something else.

For NBTB situations where the reason for B's acquired immunity ${ }^{65}$ to $\mathrm{C}$ is something other than an expired limitation period, the proposed analysis leaves open the possibility that there might be an explanation for B's acquired immunity sufficient to make that immunity a defence to the contribution claim. Those reasons could include: ${ }^{66}$

- a pre-existing contract that provides B a defence to C's claim;

- $\quad$ some other aspect of a pre-tort connection between $\mathrm{C}$ and $\mathrm{B}$ that provides $\mathrm{B}$ immunity to C's claim, assuming that immunity does not result in A's liability to C being limited to A's several proportion of C's loss; that is, only A's own share and no part of B's;

65 There is nothing in this analysis that entails a conclusion that contribution should be allowed against someone whose causal conduct was never wrongful in the broadest sense of that phrase; that is, that the conduct was always "innocent." The fact that causal conduct is "innocent" could be a sufficient juristic reason for B's gain. 
- $\quad$ something about the circumstances of a settlement between $\mathrm{B}$ and $\mathrm{C}$ providing $\mathrm{B}$ a complete release other than the fact that the amount is a reasonable estimate of B's share of C's loss;

- $\quad$ some other conduct by $\mathrm{C}$ that provides $\mathrm{B}$ a defence to C's claim even though it does not negate the existence of the right;

- $\quad$ generally, conduct by A in some sense relevant to the existence of B's immunity to $\mathrm{C}$;

- whether the immunity is procedural or substantive; and,

- whether there is a statute that either specifically or by necessary implication makes B's immunity to C, arising from a particular reason, a defence to A's contribution claim. $^{67}$

\section{Conclusion}

Contribution, properly analyzed as a claim in Unjust Enrichment or governed by equivalent principles, permits but does not require the conclusion that $\mathrm{A}$ has a contribution right notwithstanding B's immunity to a claim by $\mathrm{C}$. The analysis outlined in this article provides a coherent, principled, basis upon which a decision as to whether the contribution claim should or should not be allowed to proceed in a particular case, assuming legislation does not mandate the answer. The analysis is substantively neutral. It does not entail or prefer one or the other result. Ultimately, this neutrality exists because a condition of the analysis is that, to the extent B's immunity is relevant at all, what is relevant is the reason for that immunity. The mere fact of the immunity is not determinative.

In the NBTB situations where it is C's conduct that creates B's immunity, that fact is the basis of the justification, said to be fairness as between $\mathrm{A}$ and $\mathrm{B}$, for the current preferred position in case law, statute, and scholarship that $\mathrm{A}$ has a right of contribution against $\mathrm{B}{ }^{68}$ The analysis proposed in this article uses that justification to support the components of an analysis which permits but does not require the conclusion that the contribution right exists. What counts as "enrichment," "deprivation," "absence of justification," or "unjustness" for the purposes of a claim in unjust enrichment is a social policy question for the courts to decide. There is no reason in principle precluding the adoption of this analysis.

To date, in those jurisdictions which have dealt with the NBTB problem, the solution has either been provided by statute or, absent statute, by judicial decision. It seems implicit in the case law that the solution is seen as an exception to the result otherwise required by contribution principles, but mandated by fairness as between $\mathrm{A}$ and $\mathrm{B}$. There are explicit statements in modern contribution scholarship that, in principle, allowing A's contribution

67 For example, the interpretation of Alberta's contribution legislation by the Supreme Court of Canada in Parkland No 31 (County of) v Stetar, [1975] 2 SCR 884.

68 The alternative, to "punish" C, that is to limit C's recovery from A by some amount to compensate A for A's loss of contribution rights from B as a result of C's conduct, is usually rejected in jurisdictions whose legal systems are based on English law. The Republic of Ireland is one country which adopted that solution. 
claim to succeed in the NBTB situation is inconsistent with unjust enrichment principles. ${ }^{69}$ If that position is correct, then allowing the claim to succeed is necessarily an exception. If the analysis outlined in this article is correct, then allowing a contribution claim in an NBTB instance is not an exception to principle. It is consistent with principle.

I wrote that the question of whether, in principle, the NBTB problem in contribution between tortfeasors ought ever to have been a problem, at all, has a bit of an "O. Henry" answer. In principle, the answer should always have been no, unless legislation mandates a different answer. The decision as to whether the explanation for B's immunity to $\mathrm{C}$ in a particular case is a juristic reason for the enrichment should be consistent with the explanation and decision that would be given for contribution claims in other areas of joint obligation. There is nothing about contribution between tortfeasors that requires a different answer. As between co-debtors, co-sureties, and co-trustees, ${ }^{70}$ it has been English law for about 120 years that the right of contribution between the co-debtors continues to exist although the right of the creditor against one of them has become statute barred by the expiration of a limitation period. ${ }^{71}$ I do not know, as of writing, whether there has even been a Canadian decision on point. ${ }^{72}$

It is worth asking why the analogy to the law in other areas of obligation has never been considered in the reported decisions. Perhaps what is more apt than "O. Henry" is a Homer Simpson "D'oh.",73

See supra note 31 .

And co-sureties and co-trustees.

See Williams, Joint Obligations, supra note 15 at 165-66: “The right of contribution ... does not depend on a present common obligation between the debtor who pays the debt and the debtor against whom ... contribution is sought. It is enough that the joint or joint and several obligation existed at some period in the past."

72 My computer searches and cursory text search did not produce any Canadian decisions on this point. I used Westlaw and CanLII. The Canadian decisions applying the cases cited by Williams did so for a different issue: when the cause of action for contribution arose. Nonetheless, the tenor of the comments about the reasoning in the English cases suggests the Canadian judges would have accepted the proposition as stated by Williams had the need arisen.

73 It is even more apt applied to me. I quoted the passage from Williams, Joint Obligations in Cheifetz, Apportionment, supra note 10 at 41, and referred to it again at 44-45. The quotation appears in the section of the text that deals with the NBTB issue, albeit solely in relation to the contribution right created by the Ontario Negligence Act. I introduced the quotation by stating, "Contribution between tortfeasors should be dealt with analogously to contribution between co-debtors" (ibid at 41). 